\title{
Two new species of Lejeuneaceae tribe Lejeuneeae (Marchantiophyta) from Colombia
}

\section{S. Robbert Gradstein \& Anna Luiza Ilkiu-Borges}

Two new species of Lejeuneaceae tribe Lejeuneeae (Marchantiophyta) from Colombia. - Acta Mus. Siles. Sci. Natur., 68: 29-36, 2019.

\begin{abstract}
We describe the new liverwort species Lejeunea ryszardii from montane rainforest in the Central Cordillera of Colombia (Dept. Quindío) and Rectolejeunea halinae from submontane rainforest in the Western Cordillera (Dept. Risaralda). Both species stand out by copious vegetative reproduction via caducous leaves. Lejeunea ryszardii resembles the Caribbean L. paucidentata in the leaf lobes with toothed margins and a narrow base but strikingly differs from the latter species in: 1) leaf margins with mamillose cells, which are sometimes crowned by a small papilla, and with scattered rhizoids with or without a tooth-like base; 2) lobules with narrowly elongate, curved, sharp tooth; 3) stem epidermis brownish and somewhat thick-walled; 4) copious production of caducous leaf lobes. Moreover, $L$. ryszardii is dark green to brown in color and probably dioicous while L. paucidentata is light green and autoicous. Rectolejeunea halinae resembles the neotropical $R$. flagelliformis in having ciliate caducous leaves but clearly differs from the latter in the pointed leaf tips, the presence of ocelli in underleaves, and the flagelliform shoots with flat, entire-margined underleaves. The discovery of these new species adds two further endemic taxa to the rich bryophyte flora of the Colombian Andes.
\end{abstract}

Key words: Colombia, Lejeunea paucidentata, Lejeunea ryszardii, Rectolejeunea flagelliformis, Rectolejeunea halinae, liverworts, morphology, taxonomy.

\section{Introduction}

Colombia is one of the biologically most diverse countries of this planet. About the size of France and the Iberian Peninsula combined, Colombia harbors more species of plants than any other neotropical country except Brazil (Ulloa Ulloa et al. 2017). The recent plant catalogue of Colombia (Bernal et al. 2016) lists about 24,500 species of vascular plants and 1,650 of bryophytes (932 mosses, 703 liverworts, 15 hornworts), with about $25 \%$ of vascular plant species and $5 \%$ of bryophytes being endemic. This high diversity is undoubtedly due to the enormous variety of climate, soils and topography in Colombia resulting in a great diversity of vegetation formations such as the wet lowland rainforests of Amazonia and the Chocó region, the semi-deserts along the Caribbean Coast and the lush montane forests and harsh páramos of the Andes, which is split in three huge cordilleras and reaches its highest elevation in the Sierra Nevada de Santa Marta (5775 m), the world's highest coastal mountain.

Based on the ongoing studies of the first author on the liverwort flora of Colombia (e.g., Gradstein 2016; Gradstein \& Reeb 2018; Gradstein et al. 2018a, 2018b), several species new to science were recently described (Gradstein \& Reiner-Drehwald, 2017a, 2017b; ReinerDrehwald \& Gradstein 2018). Here we describe two further new liverwort species, both in the tribe Lejeuneeae, the most speciose group of the family Lejeuneaceae with well over one thousand species in about 45 genera, including large groups such as Cheilolejeunea, Cololejeunea, Colura, Diplasiolejeunea, Drepanolejeunea and Lejeunea. Characteristic features of the Lejeuneeae are the thin stems with ventral merophytes usually only 1-2 epidermal cells wide, the predominance of bifid underleaves, the sporophyte foot made up of only 3 transverse cell rings, the seta made up of 16 rows of cells (12 outer rows, 4 inner rows) and the butterfly- or broadly quadrate-shaped hinge of the capsule wall (Gradstein 2013). 
The generic classification of Lejeuneeae has long been considered notoriously difficult due to the common occurrence of parallel evolution in the group and the lack of stable generic characters (e.g., Schuster 1963; Gradstein et al. 2003). Recent taxonomic studies based on integrated molecular and morphological analyses, however, have considerably improved our understanding of systematic relationships within the tribe (e.g., Dong et al. 2013; Heinrichs et al. 2013, 2014; Wei et al. 2014; Schäfer-Verwimp et al. 2014; Ye et al. 2015; Bechteler et al. 2016; Zhu \& Shu 2017; Zhu et al. 2017).

The two new species of Lejeuneeae described in this paper were discovered during fieldwork by the first author in Colombia. Their discovery adds two further endemic species to the rich bryophyte flora of the country. It is a pleasure to dedicate the new species to Halina Bednarek-Ochyra and Ryszard Ochyra at the occasion of their 60th and 70th birthdays, respectively, and in recognition of their major contributions to bryology.

\section{Descriptions of the new species}

Lejeunea ryszardii Gradst. \& Ilkiu-Borges sp. nov.

DIAGNOSIS: Stems and branches partly denuded by abundant production of caducous leaf lobes. Stems brownish, epidermal cell walls slightly thickened. Leaf lobes with a very narrow base, apex acuminate, margins irregularly crenate and with scattered rhizoids and teeth terminating in a rhizoid. Lobules flask-shaped, ca. 1/3× leaf length, with a narrowly elongate, curved tooth.

TYPE: Colombia, Department Quindío, Municipio Filandia, Vereda Cruces, Granga Experimental "Bengala", 1900-2000 m, old secondary montane forest on steep slope, on base of tree trunk, 30 April 2018, S. R. Gradstein \& C. Agudelo-H. 12726a (holotype: HUQ!; isotypes: MG!, PC!).

EPONYMY: dedicated to Ryszard Ochyra at the occasion of his 70th birthday.

Plants dull dark green to brownish green when dry, to $1.5 \mathrm{~cm}$ long, main stem with leaves ca. $1 \mathrm{~mm}$ wide, sparsely to densely pinnately branched, all branches of the Lejeunea-type, slightly smaller than the main shoot. Stems and branches partly denuded by abundant production of caducous leaf lobes, denuded shoots bearing lobules and underleaves only. Stems brown, 70-90 $\mu$ m wide, made up of 7 rows of epidermal cells surrounding 10-13 rows of narrower medullary cells, epidermal cells subrectangular in ventral view, 35-50 $\times 25-35 \mu \mathrm{m}$, slightly less elongate in dorsal view, epidermal cell walls slightly thickened, pale brown; ventral merophyte 2 epidermal cells wide. Leaves contiguous to subimbricate, widely spreading. Leaf lobes asymmetrically ovate-falcate, slightly convex, ca. $0.5 \times 0.35-0.45 \mathrm{~mm}$, apex acuminate, acumen 2-6 cells long, 2-3 cells wide in the lower half, tip of 1-2 subquadrate cells, frequently terminating in a short rhizoid, the rhizoid to $0.1 \mathrm{~mm}$ long; leaf margins irregularly crenate due to mamillose cells, the cells thin-walled or, when large, crowned by a small papilla, margins furthermore with scattered rhizoids (especially on leaves near denuded shoots) and 2-5 irregular blunt teeth especially on the dorsal margin, less commonly on the ventral margin, the teeth 1-2 cells long, usually terminating in a short rhizoid; leaf lobes conspicuously narrowed to the base, insertion line $0.1-0.14 \mathrm{~mm}$ long, ca. $1 / 3$ the width of the base, basal margin of lobe \pm parallel to stem, lobe conspicuously recessed along the line of detachment opposite the free margin of the lobule. Median leaf cells hexagonal, isodiametrical to elongate, 25-35 $\times 20-27 \mu \mathrm{m}$, marginal leaf cells smaller, quadrate to subrectangular 15-20 $\times 10-15 \mu \mathrm{m}$, basal cells similar to median cells or more elongate; cell walls with small, simple or slightly radiate trigones and \pm without intermediate thickenings; cuticle smooth; oil bodies not observed. Lobules well-developed, not reduced, strongly inflated, diverging at an oblique angle with the stem, curved and shortly flask-shaped with a narrow, rounded orifice, 150-180 $\times 100-120$ $\mu \mathrm{m}, 1.5 \times$ longer than wide, ca. $1 / 3 \times$ lobe length, free margin appressed to the surface of the lobe, bordered in the upper half (proximal to the apex) by 3 transversely narrowed cells which are oriented obliquely towards the free margin and 3-4× wider than long, apical tooth long, 30-38 $\times 12-13 \mu \mathrm{m}, 2.5-3 \times$ longer than wide, curved outwards, apical free margin (between the tooth and the junction of the free margin and the ventral lobe margin) bordered by 4 rectangular, long than wide cells which are sometimes protruding outwards, free margin not continuing along the ventral margin of the leaf lobe; keel strongly arched, smooth, sinus strongly indented, angle between keel and ventral margin of the lobe sharp, ca. $90^{\circ}$. Underleaves distant, flat, \pm appressed to the stem, broadly ovate, 0.15 $0.18 \times 0.18-0.21 \mathrm{~mm}$, slightly wider than long $2.5-3 \times$ stem width, slightly smaller on branches, bifid to $1 / 2$, sinus V-shaped, lobes straight, triangular, 5-6 cells wide at base, apex subacute, former by 1 cell, margins curved, entire, base rounded, cordate, insertion line curved, at outer angles with a prominent, large cell (belonging to the lobule); rhizoid disc small, rhizoids short, colorless, often absent. Dioicous (?); gynoecia not observed. Androecia terminal or intercalary on elongate or short-specialized branched, male bracts strongly swollen, suberect, subimbricate, in 2-5 pairs, lobes smaller than vegetative leaf lobes, margins crenate, lobules hypostatic, almost as large as lobe; 

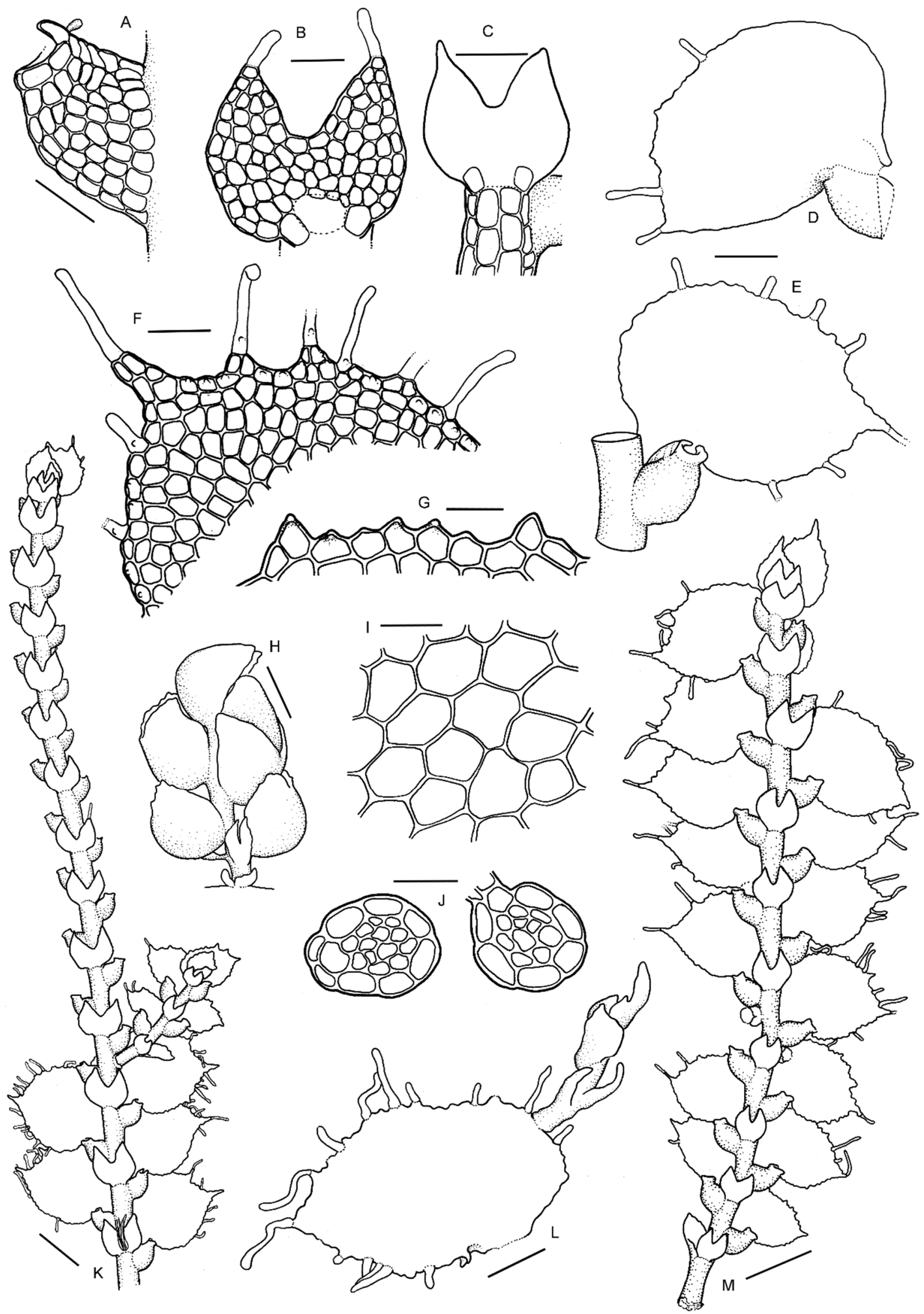

Fig 1: A-M - Lejeunea ryszardii. A - Lobule. B - Underleaf with apices terminating in a short rhizoid. C - Underleaf and portion of stem. D - Leaf, dorsal view. $\mathbf{E}$ - Leaf, ventral view. F-G - Leaf margins. $\mathbf{H}$ - Androecia. $\mathbf{I}$ - Median cells of the leaf lobe. $\mathbf{J}$ - Cross sections of stem. $\mathbf{K}$ - Habit with shoot portion producing caducous leaf lobes, ventral view. $\mathbf{L}$ - Caducous leaf with rhizoids and juvenile plantlet. $\mathbf{M}-$ Habit, ventral view. (A, B, F, J= 50 $\mu \mathrm{m} ; \mathrm{D}, \mathrm{E}, \mathrm{H}, \mathrm{L}=100 \mu \mathrm{m} ; \mathrm{G}, \mathrm{I}=25 \mu \mathrm{m} ; \mathrm{K}, \mathrm{M}=250 \mu \mathrm{m})$. 
keel arched, smooth in the lower half, crenate in the upper half; antheridia two (?) per bract; one male bract retricted to the base of spike. Vegetative reproduction abundantly by caducous leaf lobes, the lobes ovate to ovate-oblong, plane, 0.3-0.45 × 0.25-0.3 mm, otherwise as in stem leaves.

DISTRIBUTION AND HABITAT: Lejeunea ryszardii is known from one locality on the western slope of the Colombian Central Cordillera, in the department of Quindío. The new species was growing on the base of a large tree in an old secondary montane forest at about $2000 \mathrm{~m}$, on rather smooth bark and in a dense mat of various species of Lejeuneeae. Accompaying species included Lejeunea aphanes Spruce, L. concinnula Spruce \& Steph., L. debilis (Lehm. \& Lindenb.) Mont. \& Nees, Microlejeunea epiphylla Bischl. and Otigoniolejeunea huctumalcensis (Lindenb. \& Gottsche) Y.M.Wei et al.

DISCUSSION: Lejeunea ryszardii is readily recognized by: 1) stems and branches partly denuded by caducous leaf lobes; 2) leaf lobes asymmetrically ovate-falcate, conspicuously narrowed to the base, apex acuminate and usually terminating in a rhizoid, margins irregularly crenate by mamillose cells which are occasionally crowned by a small papilla, and with short teeth and scattered rhizoids with or without a tooth-like base; 3) lobules swollen, flask-shaped, never reduced, with a narrowly elongate, curved tooth; 4) stems with a slightly thick-walled, brownish-colored epidermis. The new species seems to be most closely related to L. paucidentata (Steph.) Grolle, a species widespread in the Caribbean region where it is known from Cuba, Jamaica, the Dominican Republic, Puerto Rico, Guadeloupe and Dominica (ReinerDrehwald \& Goda 2000; Schäfer-Verwimp \& van Melick 2016). The two species share toothed leaf lobes with a narrow base, small inflated lobules and small bifid underleaves (maximally $3 \times$ stem width) with entire margins and a cuneate to rounded base. Lejeunea paucidentata differs sharply from $L$. ryszardii, however, in the absence of caducous leaf lobes, the leaf margins with sharp teeth which are not terminating in a rhizoid, the absence of marginal rhizoids and papillate mamillae, the short, straight lobule tooth (15-25 $\mu \mathrm{m}$ long), and the colorless, thin-walled stem epidermis (see Reiner-Drehwald \& Goda 2000). Moreover, L. paucidentata is lighter green in color and autoicous, and usually copicously fertile; L. ryszardii, on the other hand, is only known from male plants and is probably dioicous. In its putative dioicy, L. ryszardii is similar to other asexually reproducing Lejeunea species of tropical America, all of which are dioicous (L. cancellata Nees \& Mont., L. concinnula, L. deplanata Nees, L. galeata Spruce, L. laetevirens Nees \& Mont., L. oligoclada Spruce, L. phyllobola Nees \& Mont., L. ptosimophylla C.Massal., L. rionegrensis Spruce, L. tapajosensis Spruce) with exception of the autoicous L. angusta (Lehm. \& Lindenb.) Mont.

Lejeunea ryszardii and L. paucidentata also differ in geographical distribution, L. ryszardii occurring in the Andes and L. paucidentata in the West Indies. The distribution of most neotropical Lejeunea species remains incompletely known (Reiner-Drehwald et al. 2013), however, and L. ryszardii and L. paucidentata may thus well be more widely distributed than is currently known and have overlapping ranges. Indeed, several Caribbean species extend to the Andes of Colombia, for example Alobiellopsis dominicensis (Spruce) Fulford, Bazzania eggersiana Steph. Pagán, Ceratolejeunea rubiginosa Steph., Cheilolejeunea lineata, Cololejeunea antillana Pócs, Drepanolejeunea evansii Bischl., Fuscocephaloziopsis biloba (Herzog) Fulford, Harpalejeunea tridens (Besch. \& Spruce) Steph., Lejeunea bermudiana (A.Evans) R.M.Schust., Lepidozia patens Lindenb., Marchantia inflexa Nees \& Mont., Nowellia evansii Grolle, Plagiochila arcuata Lindenb., P. eggersii Inoue, P. husnotii Steph., Prionolejeunea ampliretis Herzog, P. arguta (Nees) Steph., P. trachyodes (Spruce) Steph. and Radula fendleri Steph. (Gradstein \& Uribe 2016; Gradstein unpubl.). The occurrence of L. paucidentata in Colombia, or L. ryszardii in the West Indies, may therefore be possible. 
DIAGNOSIS: Leaf apex predominantly acute to apiculate to shortly acuminate. Ocelli present in leaves and underleaves. Caducous leaves with cilia. Underleaves on flagella flat, with entire margins.

TYPE: Colombia, Cordillera Occidental, Department Risaralda, Mistrato, along trail from Jeguadas to Puerto de Oro, ca. $1200 \mathrm{~m}$, submontane rainforest, on branches in the forest canopy, 27 July 1992, Gradstein 8538 (holotype COL, isotypes GOET!, MG!, PC!).

EPONYMY: dedicated to Halina Bednarek-Ochyra at the occasion of her 60th birthday.

DESCRIPTION: Plants pale green, very small, to $6 \mathrm{~mm}$ long, ca. $1 \mathrm{~mm}$ wide, growing appressed flat to ascending, branched at the base of the stem, branching Lejeunea-type, shoot apex frequently terminating in a leafless flagellum with underleaves. Stems rather rigid, 80-90 $\mu \mathrm{m}$ in diameter, rounded in cross section, of 7-8 epidermal cells surrounding the same number of medullary cells, all stem cells thick-walled, walls colorless. Leaves imbricate, obliquely to widely spreading, insertion shortly J-shaped (Fig. 2E). Leaf lobes convex, asymmetrically obvate-oblong, 0.55-0.6 x 0.35-0.4 mm, becoming progressively smaller towards the base of the stem, length of insertion ca. $2 / 5$ of leaf width, margins slightly crenulate, with or without a few blunt, rudimentary teeth, becoming ciliate in leaves at the base of the flagella, apex flat or recurved, acute to apiculate to shortly acuminate on welldeveloped leaves, rounded on small basal leaves. Cells subisodiametrical-hexagonal, small, 14-20 $\mu \mathrm{m}$ in midleaf, becoming slightly larger towards the base, walls uniformly thickened; oil bodies not seen; ocelli present in all leaves except in the small leaves at the stem base, 2-3(-4) large dark-brown ocelli present at the leaf base (2-3x larger than normal cells) and forming a short row, (1-)3-10 much smaller, pale-colored ocelli present scattered high up in the lamina, as large as normal cells or slightly smaller. Lobules ovate to ovate-oblong, $1.5-2 \times$ longer than wide, ca. $1 / 3 \times$ leaf length (ca. $1 / 2 \times$ leaf length in small leaves at the shoot base), inflated, becoming flattened towards apex, free margin inflexed in the lower half, flattened towards apex, cells of the free margin rectangular in the lower half, quadrate towards apex, the apex with a long, falcate tooth, 35-50 $\mu \mathrm{m}$ long, 3-4x longer than wide, thick-walled; lobule cells similar to lobe cells but smaller, ocelli lacking in the lobule; keel curved, making a wide angle with the ventral margin of the leaf lobe. Underleaves distant to subimbricate, flat and appressed to stem, orbicular to slightly longer than wide, ca. $0.25 \mathrm{~mm}$ long and $0.2-0.25 \mathrm{~mm}$ wide, $2-2.5 \times$ stem width, bifid to 2/5-1/2, apex of underleaf lobes acute, of 1-2 cells in a row, outer margins entire or bluntly angled, bases cuneate and shortly decurrent, insertion almost straight; cells similar to lobe cells but smaller; ocelli present, 2-5 per underleaf, similar to those in the leaf lamina (ocelli absent in small underleaves at the shoot base). Vegetative reproduction by caducous leaves produced on terminal flagelliform shoots; flagellar stems with 7-8 swollen epidermal cells surrounding the same number of medullary cells, all stem cells thin-walled; caducous leaves flat, without or a with a highly reduced lobule, margin with 3-10 cilia consisting of a row of 1-5 quadrate to subrectangular cells tipped by a short rhizoid (rhizoid 1-4x longer than the cells of the cilia), base of the cilia 2 cells wide; cells of caducous leaves similar to those of leaf lobes but with slightly more pronounced trigones, ocelli in caducous leaves light brownish, 4-15 per leaf, scattered (sometimes 2 adjacent), large dark brown basal ocelli lacking; underleaves of flagella mostly appressed to the stem and with entire margins. Gametoecia not observed.

DISTRIBUTION AND HABITAT: Rectolejeunea halinae is only known from the type locality on the western slope of the Colombian Western Cordillera, in the department of Risaralda. The new species was growing in loose mats on canopy branches in submontane rainforest at about 1200 $\mathrm{m}$, in a ramicolous bryophyte community rich in members of Lejeuneaceae including Bryopteris filicina (Sw.) Nees, Ceratolejeunea cornuta (Lindenb.) Steph., Cyclolejeunea peruviana (Lehm. \& Lindenb.) A.Evans, Drepanolejeunea biocellata A.Evans, Lejeunea flava (Sw.) Nees, Lepidolejeunea cordifissa (Taylor) M.E.Reiner, L. involuta (Gottsche) Grolle, Microlejeunea acutifolia Steph., Stictolejeunea squamata (Willd.) Schiffn. and the newly described Cheilolejeunea schiavoneana M.E.Reiner \& Gradst. (Gradstein \& Reiner-Drehwald 2017b).

DISCUSSION: Rectolejeunea was recently reviewed by Reiner-Drehwald \& Grolle (2012) who accepted five species in the genus: $R$. berteroana (Steph.) A.Evans (correct name: $R$. versifolia [Schiffn.] L.Soderstr. \& A.Hagborg; see Söderström et al. 2015), R. emarginuliflora (Schiffn.) A.Evans, $R$. flagelliformis A.Evans and $R$. truncatilobula C.J.Bastos in tropical America, and $R$. queenslandica (B.M.Thiers) X.L.He in tropical Australia. However, R. truncatiloba was recently transferred to the new, monospecific genus Yanoella R.L.Zhu et al., whereas $R$. queenslandica probably belongs to Thiersianthus R.L.Zhu et al., a genus recently described from Borneo (Zhu et al. 2018). Reiner-Drehwald \& Grolle (2012) listed two further species 


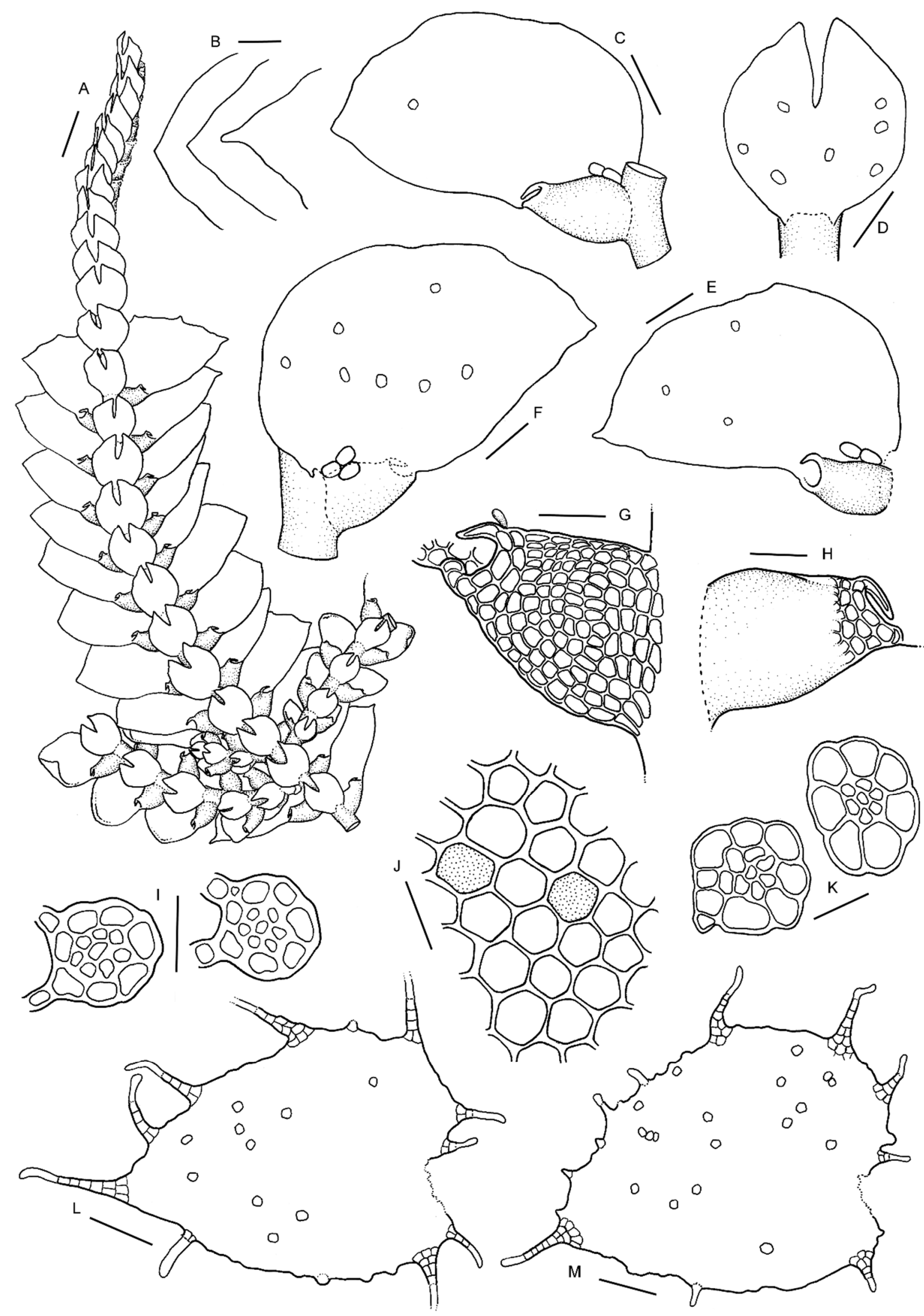

Fig 2: A-M - Rectolejeunea halinae. A - Habit with terminal flagelliform shoot producing caducous leaves. B - Leaf apices. C - Leaf, ventral view. D - Underleaf showing ocelli. E - Leaf, ventral view. F - Leaf, ventral view. G-H - Lobules. I - Cross section of a stem. J - Median cells of leaf lobe showing two ocelli. K - Cross section of stem from flagelliform shoots. $\mathbf{L}-\mathbf{M}$ - Caducous leaves with cilia and rhizoids. $(A=250 \mu \mathrm{m}, \mathrm{B}, \mathrm{G}, \mathrm{H}, \mathrm{I}$, $\mathrm{K}=50 \mu \mathrm{m} ; \mathrm{C}, \mathrm{D}, \mathrm{F}, \mathrm{L}, \mathrm{M}=100 \mu \mathrm{m} ; \mathrm{J}=25 \mu \mathrm{m})$. 
as doubtful members of Rectolejeunea, $R$. colombiana R.M.Schust. and $R$. intermedia R.M.Schust. (both from Colombia), but according to Zhu et al. (2018) both species must be excluded from Rectolejeunea. Rectolejeunea colombiana has Lejeunea-type innovations and belongs in the genus Lejeunea (Zhu et al. 2018); probably it is a synonym of L. phyllobola Nees \& Mont. (Gradstein, unpubl.). Rectolejeunea intermedia, on the other hand, has ocelli and is probably conspecific with Otigoniolejeunea huctumalcensis (Gradstein, unpubl.).

As a result, only four species remain in Rectolejeunea, $R$. emarginuliflora, $R$. flagelliformis, $R$. versifolia and the here described $R$. halinae; all four are restricted to the Neotropics. The main features of the genus are: 1) plants very small, often less than $1 \mathrm{~mm}$ wide; 2) lobules ca. 1/4 of leaf length, strongly inflated, with a truncate apex and a long, falcate tooth (tooth occasionally short in $R$. emarginuliflora and $R$. versifolia); 3 ) leaf cells very small, less than $20 \mu \mathrm{m}$ long in midleaf, with thin or uniformly thickened walls, trigones absent, cuticle smooth, oil bodies in normal leaf cells usually absent; 4) ocelli present at leaf base and scattered through the leaf lobe, sometimes also present in underleaves ( $R$. emarginuliflora, $R$. halinae); $5)$ vegetative reproduction by small caducous leaves produced on specialized flagelliform shoots. Species with caducous leaves produced on unspecialized shoots, many of which were assigned to Rectolejeunea in the past (see Schuster [2000] and Reiner-Drehwald \& Grolle [2012]), are excluded from the genus.

The new species $R$. halinae is readily recognized by the pointed leaf apex (acute to apiculate to shortly acuminate). In all other Rectolejeunea species the leaf apex is rounded; exceptionally, leaves just below the flagelliform shoot in $R$. flagelliformis have pointed tips. The latter species shares the presence of ciliate caducous leaves with $R$. halinae and shows greatest similarity to the new species. Indeed, $R$. halinae was tentatively identified as $R$. flagelliformis by Reiner-Drehwald \& Grolle (2012, p. 458). Rectolejeunea flagelliformis clearly differs from $R$. halinae, however, by the absence of ocelli in underleaves, the flagelliform branches with squarrose underleaves with toothed margins, and the mostly rounded leaf tips. The two species possibly differ also in sexuality as $R$. flagelliformis is autoicous, and is usually copiously fertile, whereas $R$. halina lacks gametoecia and may be dioicous.

Acknowledgments: The first author is indebted to Alfons Schäfer-Verwimp for information on Lejeunea paucidentata and for making specimens available for study, to Carlos Agudelo-H. (Universidad del Quindio, Colombia) for organizing fieldwork of the first author in the Central Cordillera of Colombia in 2018, and to the National Geographic Society (grant \# 46 91-91 to the late J.-P. Frahm) for supporting fieldwork in the Western Cordillera of Colombia in 1992.

\section{References}

Bechteler J., Lee G.E., Schäfer-Verwimp A., Pócs T., Peralta D.F., Renner M.A.M., Schneider H. \& Heinrichs J. (2016): Towards a monophyletic classification of Lejeuneaceae IV: reinstatement of Allorgella, transfer of Microlejeunea aphanella to Vitalianthus and refinements of the subtribal classification. - Plant Systematics and Evolution 302: 187-201.

Bernal R., Gradstein S.R. \& Celis M. (eds) (2016): Catalogó de plantas y líquenes de Colombia, 2 vols. Universidad Nacional de Colombia, Bogotá, $3058 \mathrm{pp}$.

Dong S., Schäfer-Verwimp A., Pócs T., Feldberg K., Czumaj A., Schmidt A.R., Schneider H. \& Heinrichs J. (2013): Size doesn't matter - recircumscription of Microlejeunea based on molecular and morphological evidence. - Phytotaxa 85: 41-55.

Gradstein S.R. (2013): A classification of Lejeuneaceae (Marchantiophyta) based on molecular and morphological evidence. - Phytotaxa 100: 6-20.

- (2016): The genus Plagiochila (Marchantiophyta) in Colombia. - Revista de la Academía Colombiana de Ciencias Exactas, Fisicas y Naturales 40: 104-136.

Gradstein S.R. \& Ilkiu-Borges A.L. (2018): An overview of the Afro-American genus Haplolejeunea with description of two new species from South America. - Nova Hedwigia 107: 423-436.

Gradstein S.R. \& Reeb C. (2018): The genus Riccardia (Aneuraceae) in Colombia and Ecuador. Cryptogamie, Bryology 39: 515-540. 
Gradstein S.R. \& Uribe J. (2016): Marchantiophyta, 282-352 pp. In: Bernal R., Gradstein S.R. \& Celis M. (eds), Catálogo de plantas y líquenes de Colombia. Vol. 1. Universidad Nacional de Colombia, Bogotá.

Gradstein S.R., Uribe-M. J., Gil-N. J., Morales C. \& Negritto M. (2018a): Liverworts new to Colombia. Caldasia 40: 82-90.

Gradstein S.R., Vanderpoorten A., van Reenen G.B.A. \& Cleef A.M. (2018b): Mass occurrence of Herbertus sendtneri (Herbertaceae) in a glacial lake in the Andes of Colombia. - Revista de la Academía Colombiana de Ciencias Exactas, Fisicas y Naturales 42: 221-219.

Gradstein S.R. \& Reiner-Drehwald M.E. (2017a): A new species of Cyclolejeunea (Marchantiophyta: Lejeuneaceae) from the Chocó, Colombia. - Bryophyte Diversity and Evolution 39: 21-27.

- (2017b): Cheilolejeunea schiavoneana, a remarkable new liverwort species from Colombia. - Boletin de la Sociedad Botánica de Argentina 52: 325-330.

Gradstein S.R., Reiner-Drehwald M.E. \& Schneider H. (2003): A phylogenetic analysis of the genera of Lejeuneaceae (Hepaticae). - Botanical Journal of the Linnean Society 143: 391-410.

Heinrichs J., Dong S., Schäfer-Verwimp A., Pócs T., Feldberg K., Czumaj A., Schmidt A.R., Reitner J., Renner M.A.M., Hentschel J., Stech M. \& Schneider H. (2013): Molecular phylogeny of the leafy liverwort Lejeunea (Porellales). - PLoS ONE 8: e82547.

Heinrichs J., Dong S., Schäfer-Verwimp A., Peralta D.F., Feldberg K., Schmidt A.R. \& Schneider H. (2014): Towards a monophyletic classification of Lejeuneaceae II: subtribes Pycnolejeuneinae and Xylolejeuneinae subtr. nov., transfer of Otolejeunea to Lepidolejeuneinae, and generic refinements. Phytotaxa 163: 61-76.

Reiner-Drehwald M.E. \& Goda A. (2000): Revision of the genus Crossotolejeunea (Lejeuneaceae, Hepaticae). - J. Hattori Bot. Lab. 89: 1-54.

Reiner-Drehwald M.E. \& Gradstein (2018): A further new species of Lejeuneaceae (Marchantiophyta) from the Chocó of Colombia: Pycnolejeunea chocoensis. - Cryptogamie, Bryologie 39: 325-330.

Reiner-Drehwald M.E. \& Grolle R. (2012): Review of the genus Rectolejeunea (Lejeuneaceae, Marchantiophyta). - Nova Hedwigia 95: 451-482.

Reiner-Drehwald M.E., Salazar Allen N. \& C. Chung C. (2013): New combinations and synonyms in neotropical Lejeuneaceae (Marchantiophyta), with description of Lejeunea tamasii, a new species from Barro Colorado Island, Panama. - Polish Botanical Journal 58: 419-426.

Schäfer-Verwimp A. \& van Melick H. (2016): A contribution to the bryophyte flora of Jamaica. Cryptogamie, Bryologie 37: 305-348.

Schäfer-Verwimp A., Feldberg K., Dong S., Van Melick H., Peralta D.F., Schmidt A.R., Schneider H. \& Heinrichs J. (2014): Towards a monophyletic classification of Lejeuneaceae III: the systematic position of Leiolejeunea. - Phytotaxa 170: 187-193.

Schuster R.M. (1963a): An annotated synopsis of the genera and subgenera of Lejeuneaceae. - Beihefte zur Nova Hedwigia 9: 1-203.

- (2000): Studies on Lejeuneaceae, II. Rectolejeunea Evs emend. Schust. (Lejeuneoideae). - J. Hattori Bot. Lab. 89: 113-150.

Ulloa Ulloa C., Acevedo-Rodríguez P., Beck S., Belgrano M.J., Bernal R., Berry P.E., Brako L., Celis M., Davidse G., Forzza R., Gradstein R., Hokche H., León B., León-Yánez S., Magill R.E., Neill D.A., Nee M., Raven P., Stimmel H., Strong M.T., Villaseñor J.L., Zarucchi J.L., Zuloaga F.O. \& Jørgens en P.M. (2017): How many plant species occur in the New World. - Science 358: 1614-1617.

Wei Y.M., Zhu R.L. \& Gradstein S.R. (2014): Notes on early land plants today. 49. On Lejeunea huctumalcensis Lindenb. \& Gottsche and the resurrection of Otigoniolejeunea (Spruce) Schiffn., an older name for Physantholejeunea R. M. Schust. (Marchantiophyta, Lejeuneaceae). - Phytotaxa 162: 236-238.

Ye W., Gradstein S.R., Shaw J.A., Shaw B., Ho B.C., Schäfer-Verwimp A., Pócs T., Heinrichs J. \& Zhu R.L. (2015): Phylogeny and classification of Lejeuneaceae subtribe Cheilolejeuneinae (Marchantiophyta) based on nuclear and plastid molecular markers. - Cryptogamie, Bryologie 36: 313-333.

Zhu R.L. \& Shu L. (2017): The systematic position of Microlejeunea ocellata (Marchantiophyta: Lejeuneaceae), an extroardinary species endemic to Australia and New Zealand. - The Bryologist 121: 158-165.

Zhu R.L., Shu L., Mustapeng M. \& Suleiman M. (2017): Thiersianthus (Marchantiophyta: Lejeuneaceae), a new genus from lowland rainforests in Borneo. - The Bryologist 120: 511-520.

Authors' adresses: S. Robbert Gradstein, Muséum National d'Histoire Naturelle, Institut de Systématique, Évolution, Biodiversité (UMR 7205), 12 Rue Buffon, 75005 Paris, France.

E-mail: gradstein@mnhn.fr

Anna Luiza Ilkiu-Borges, Museu Paraense Emílio Goeldi, Coordenação de Botânica, Av. Magalhães Barata 376, 66040-170, Belém, Pará, Brazil.

E-mail: ilkiu-borges@museu-goeldi.br 